\title{
Role of conventional energy in rural development in India: feasibility analysis of solar drying technology
}

\author{
K. Varalakshmi ${ }^{1}$
}

Received: 12 October 2015 / Accepted: 2 June 2016/Published online: 11 July 2016

(c) The Author(s) 2016. This article is published with open access at Springerlink.com

\begin{abstract}
The paper examines the role of technology for rural development/empowerment. For the purpose of the feasibility, dried meat production with solar energy is considered on a small scale unit of $50 \mathrm{~kg} /$ day. The study shows that the small scale production of sundried meat products require capital investment of US\$ 0.17 lakhs. Total annual expenditure was estimated as US\$ 0.43 lakhs. Cost of production of dried meat comes to US\$12.38/kg with variable costs of US\$ 10.78 and fixed costs of US\$ $1.6 / \mathrm{kg}$. Considering all the discounting measures like net present value (Rs. 0.09 lakhs) IRR (41\%) BCR (1.54) and payback period (3.21 years), sun dried meat production in rural areas can become a viable option for farmers to serve dual role of employment generation and profits. The results showed potential and worthiness of sun drying technology for the rural development/empowerment.
\end{abstract}

Keywords Sun drying · Technology - Empowerment . Rural development $\cdot$ Economics $\cdot$ Small scale

\section{Introduction}

India is predominantly an agricultural economy with more than $60 \%$ of people engaged in agriculture [1]. Agriculture and animal husbandry in India are interwoven with the intricate fabric of the society in cultural, religious and economical ways as mixed farming and livestock rearing form an integral part of rural living. Livestock provides draught power, rural transport,

\footnotetext{
K. Varalakshmi

kvslbk@yahoo.co.in

1 National Research Centre on Meat, Hyderabad 500092, India
}

manure, fuel, milk and meat. It has been the livestock that provides livelihoods to the farmers through secondary income and also serves as insurance in the event of crop failure [2]. Since agriculture is seasonal and $60 \%$ of agriculture is rainfed in India [1], rural farmers face the problem of off-season unemployment especially in summer. There are some initiatives by government like Mahatma Gandhi National Rural Employment Guarantee schemes (MNREGA) [3] to provide livelihoods to the farmers during off-season, still seasonal unemployment exists in rural India.

Livestock not only provide livelihoods in crop failures but also gives regular profit and employment in off-season through meat processing. Sun drying is one such technology where off-season can be utilized to generate employment and profits through the use of conventional sun energy. Combining livestock and sun drying technology to produce the sun dried meat products will result in rural empowerment and development through employment generation and profits. Thus, technology plays significant role in national development [4].

India is the largest producer of meat with production of 5.94 millon tons of meat in the year 2012-2013 [5]. Out of which, $20-30 \%$ is being spoiled every year due to inadequate storage facilities. Only $2 \%$ of production is processed and the remaining is consumed as fresh [6]. Because of its perishable nature, there is felt need to preserve the meat over a period of time to use it during off season. Preservation of meat can prevent the huge wastage and make them available in the off-season at remunerative prices. Drying is one such technology that promises the stable products with longer shelf life. Drying of meat in sun has been in practice for thousand years and mostly used by Nomads and Pastoralists who sort simple means to preserve meat during excess supply [7]. Sun drying increases shelf 
life of food up to 6 months, thus resulting in increased availability of foods in off-season [8].

Various drying methods, such as tray drying in hot air, freeze microwave, have been standardized for production of dried meat products [9-11]. But these technologies need sophisticated equipment and skill training, which limits its adoption at field/rural level. Lack of inadequate electricity and unavailability of skilled man power also make the machine drying more expensive option for small-scale production of dried meat products.

Though mechanical drying, powered by electricity or fuel, help in producing quality products in mass scale, they are seldom adopted by small-scale entrepreneurs and farmers of most developing countries, due to heavy installation costs involved and large operating cost because of it being energy intensive process [12]. Tray drying is viable for large-scale production.

But for small-scale production, solar drying is one such low-cost technology requiring no electricity, no skilled manpower and capital, and provides employment in rural areas during off-season. It also addresses the problems of environmental pollution coming out of processing industries as it is pollution free energy [13]. It also addresses problems of energy/fuels demand as it is renewable in nature (renewable energy). Solar energy is fast becoming an important alternative source of energy as it can be tapped at selectively low cost.

Sun meat drying is a method of producing dried meat products by keeping the meat rubbed with salt and other ingredients in the sun for a few days to remove the moisture content of the product [14].

Though sun drying is practiced since ancient times, dried meat technology has been standardized by the researchers to improve the quality of the product compared to traditional drying. But it remains to consider the economic feasibility of the drying meat in the local conditions, which represents the main objective of the present study.

With this backdrop, in this paper, we have attempted to find out the feasibility of solar energy for production of dried meat on a small scale for rural employment and development. We have worked out economics, such as processing cost, prices, and returns, by evaluation techniques.

\section{Methodology}

In this paper, cost effectiveness of sun dried meat production is analysed. The study assumed the capacity of $50 \mathrm{~kg}$ /day which is suitable for small scale users/farm families. Using input and output data, economics were worked out for dried meat chunk production on a small- scale unit. Additional success indicators or viability indicators, such as BC, profitability ratios, and feasibility ratios, were also used.

\section{Basic assumptions}

Calculations are based on the following important technical and economic presuppositions. These assumptions are related to production, working capital, finance, depreciation.

Regarding production, it is assumed that the facility will process $50 \mathrm{~kg} /$ day and operate an 8-h shift, 6 days a week, 25 weeks a year with a capacity utilization rate of $85 \%$, from first year onwards.

Regarding construction and finance, it is assumed that contribution of banks and equity will be in the ratio of $3: 1$ including subsidy component. For calculation of IRR and net present value (NPV) of the project, cost of capital/ interest rate of $12 \%$ set by commercial banks for longterm loans has been taken, whereas cost of working capital is taken as at $15 \%$ as per the rates fixed by the banks. As cost of land is not financed by banks, it is assumed that the entrepreneurs built processing unit on his own land.

Depreciation rates of 10, 20 and $10 \%$ are considered for buildings, machinery and miscellaneous assets, respectively. For the purpose of estimating working capital requirement, 15 days is assumed as storage period for raw material and final product. Work in progress is assumed as 6 days. $50 \%$ of sales are assumed as credit sales.

\section{Results and discussion}

\section{Capacity of processing plant}

\section{Installed capacity}

Capacity of the plant is $50 \mathrm{~kg} /$ day of dried meat chunks. Product yield of $45 \%$ is taken for dried meat chunks after drying loss of $55 \%$.Considering 180 working days in a year and yield of the products, the unit has an installed capacity of 4050-kg dried meat chunks. Product yield and production at full capacity will be as follows (Table 1).

\section{Capacity utilization}

The capacity utilization varies depending on the capital availability, staff efficiency and availability of raw material. The plant is assumed to start production at $85 \%$ of its installed capacity in the first year and continues in the successive years (Table 2). 
Table 1 Capacity of processing plant

\begin{tabular}{llllll}
\hline S. no. & Product & Product yield & Days & Per day capacity & $\begin{array}{c}\text { Annual output } \\
(100 \% \text { capacity })\end{array}$ \\
\hline 1 & Dried chunks & $45 \%$ & 180 & 50 & 4050 \\
\hline
\end{tabular}

Table 2 Annual capacity/capacity utilization for processing plant

\begin{tabular}{lllllllll}
\hline Year & 1 & 2 & 3 & 4 & 5 & 6 & 7 & 8 \\
\hline Installed capacity & $4050 @$ & $50 \mathrm{~kg}$ /day & $\times 180$ & days $\times 45 \%$ & & & & \\
Capacity utilization $(\%)$ & 85 & 85 & 85 & 85 & 85 & 85 & 85 & 85 \\
Output & 3443 & 3443 & 3443 & 3443 & 3443 & 3443 & 3443 & 3443 \\
\hline
\end{tabular}

\section{Project set up costs/capital investment/ infrastructure required}

The data presented in Table 3 revealed that the on construction of small unit for dried meat for family farm requires investments in buildings and equipment, drying space. The total investment value of plant for drying meat with capacity of $50 \mathrm{~kg} / \mathrm{day}$ amounts to US\$ 0.17 lakhs. If there is a suitable building in the commercial yard of the family farm, construction costs of the facility are reduced enough to carry out renovation [15].

The expenditure on buildings accounted for the maximum share of $41.65 \%$ followed by working capital margin $(20.2 \%)$ and machinery $(13.25 \%)$. It is evident from investment pattern that buildings take maximum share as more space is required for drying of meat products. As yield of the final product is only $45 \%$, raw material cost represented in working capital forms the major cost after buildings. Machinery and equipment's share is less compared to other meat products as it is based on solar energy.

Per unit investment comes to US\$ $4.28 / \mathrm{kg}$ out of which buildings account for US\$ $1.78 / \mathrm{kg}$ and working capital forms US\$ $0.86 / \mathrm{kg}$ of total project cost.
Credit linked subsidy of US\$ 0.04 lakhs is also availed through the subsidy scheme of Ministry of Food Processing Industry, GoI called Scheme of Technology Upgradation/ Establishment/Modernisation of Food Processing Industries under National Mission on Food Processing (NMFP) [16].

\section{Project economics}

\section{Production costs}

The production estimates for products are based on their output yields. The output yield/input output ratio is taken as $45 \%$ for dried meat chunks as established by studies. The information regarding annual expenditure and per $\mathrm{kg}$ expenditure in the first year in preparation of dried meat chunks has been shown in Table 4 .

It is clear from expenditure statement given in Table 4 that in total costs, for every rupee spent, raw material cost accounts for major share of US\$ 0.71 followed by labour costs (US\$ 0.12). Raw material cost per kg was estimated as US\$ 8.81 and labor costs forms the second largest item of cost in total costs next to raw material with per unit cost of US\$ $1.58 / \mathrm{kg}$.
Table 3 Project cost on of drying units

\begin{tabular}{|c|c|c|c|c|}
\hline S. no. & Description & $\begin{array}{l}\text { Total } \\
\text { (US\$ lakhs) }\end{array}$ & $\%$ & Per kg (US\$) \\
\hline 1 & Land and fencing & 0.02 & 11.36 & 29.63 \\
\hline 2 & Building & 0.07 & 41.65 & 108.64 \\
\hline 3 & Machinery and equipment (M\&E) & 0.02 & 13.25 & 34.57 \\
\hline 4 & Miscellaneous assets & 0.00 & 1.33 & 3.46 \\
\hline 5 & Escalation and contingencies & 0.01 & 6.76 & 17.63 \\
\hline 6 & Preliminary and preoperative expenses & 0.01 & 5.45 & 14.21 \\
\hline \multirow[t]{3}{*}{7} & Working capital margin & 0.03 & 20.20 & 52.69 \\
\hline & Total cost & 0.17 & 100.00 & 260.83 \\
\hline & \multicolumn{3}{|c|}{ Means of finance } & \\
\hline 1 & \multicolumn{2}{|l|}{ Equity } & & 0.04 \\
\hline 2 & \multicolumn{2}{|l|}{ Subsidy } & & 0.04 \\
\hline 3 & \multicolumn{2}{|c|}{$\begin{array}{l}\text { Effective bank } \\
\text { loan }\end{array}$} & & 0.09 \\
\hline
\end{tabular}


Table 4 Cost of production of dried meat chunks on small-scale unit

\begin{tabular}{llrr}
\hline Particulars & $\begin{array}{l}\text { Annual } \\
\text { (US\$ lakhs) }\end{array}$ & $\begin{array}{l}\text { Per kg } \\
\text { (US\$) }\end{array}$ & \multicolumn{1}{c}{$\%$} \\
\hline Raw material & 0.30 & 8.81 & 71.24 \\
$\begin{array}{l}\text { Stores, consumables and } \\
\text { packaging materials }\end{array}$ & 0.02 & 0.44 & 3.53 \\
Power & 0.00 & 0.11 & 0.87 \\
Utilities & 0.00 & 0.07 & 0.55 \\
Wages and salary & 0.05 & 1.58 & 12.74 \\
Repairs and maintenance & 0.00 & 0.07 & 0.55 \\
Rent, taxes and insurance & 0.00 & 0.11 & 0.92 \\
Admin expenses & 0.00 & 0.00 & 0.00 \\
Selling expenses & 0.01 & 0.41 & 3.32 \\
Interest on term loan & 0.01 & 0.24 & 1.93 \\
Interest on WC & 0.01 & 0.15 & 1.18 \\
Depreciation & 0.01 & 0.38 & 3.11 \\
P \& P amortization & 0.00 & 0.01 & 0.04 \\
Total & 0.43 & 12.37 & 100.00 \\
\hline
\end{tabular}

Table 5 Cost and price structure of sun dried meat products on small unit

\begin{tabular}{lcl}
\hline Item of cost & US\$/kg & $\%$ \\
\hline Variable costs & 10.78 & 87.06 \\
Fixed costs & 1.60 & 12.93 \\
Total costs & 12.38 & 100 \\
Markup @ 10 \% & 1.24 & - \\
Selling price@ 10 \% markup & 13.61 & - \\
\hline
\end{tabular}

Production of dried meat requires daily costs of US\$ 278.41 @ US\$12.37/kg, which amounts to US\$ 0.43 lakhs in the 180 days period with $85 \%$ capacity utilization with $45 \%$ yield in the first year. As expected, the costs of fresh meat as the basic raw material are dominant with $60.2 \%$ (Table 4). Fixed costs account for $8.8 \%$ of the production costs (depreciation and maintenance, general expenses and interest).

\section{Cost and price structure}

As evident from Table 5, cost of production of dried meat products on small units comes to US\$ $12.37 / \mathrm{kg}$ with variable costs of US\$10.78 and fixed costs of US\$1.6/kg. Variable and fixed costs accounts for 87.06 and $12.93 \%$ of total costs, respectively. Selling price was estimated to be US\$ $13.61 / \mathrm{kg}$ at $10 \%$ markup Table 6.

With the selling price of US\$13.61/kg, the small unit generates gross revenue of US\$ 0.47 lakhs in the first year with gross profits of US\$ 0.043 lakhs which comes to per unit profit of US\$1.24/kg. After deducting interest and
Table 6 Returns from sun dried meat production on small unit

\begin{tabular}{llc}
\hline Description & Annual (US\$ lakhs) & Per kg (US\$) \\
\hline Income & 0.47 & 13.61 \\
Expenditure & 0.43 & 12.37 \\
Profit before tax & 0.04 & 1.24 \\
Income tax & 0.00 & 0.00 \\
Vat 5 \% & 0.00 & 0.06 \\
Total taxes & 0.00 & 0.06 \\
Profit after tax & 0.04 & 1.18 \\
Non cash expenditure & 0.01 & 0.39 \\
Cash profit & 0.05 & 1.57 \\
\hline
\end{tabular}

taxes, the producer will get net profit of US\$ $1.18 / \mathrm{kg}$ with total net profit of Rs. 0.04 lakhs in the first year.

\section{Financial evaluation}

\section{Financial efficiency measures}

Ratio analysis On the basis of the projected income statement and related projections, different financial ratios are calculated and shown in Table 7.

Profitability According to the projected income statement, the project will start generating the profits in the first year of operation.

Profitability ratios (Table 7) indicate that on an average, small-scale production of dried meat production generates gross profit margin of $19.15 \%$ and operating profit margin of $11.92 \%$ and profit margin of $9.09 \%$ and net profit margin of $8.63 \%$. Operating ratio was found to be $88.08 \%$.

It shows that the direct costs incurred in the production of dried meat products accounts for $80.85 \%$ and operating expenses including administrative expenses and direct costs account for $88.08 \%$ of the profits. Interest incurred and taxes paid by the unit account for 2.83 and $0.46 \%$ of profits.

Net profit margin indicates the actual profit that is left with the company after all expenses met and it is $8.63 \%$ in this case. All the profitability ratios show an increasing trend over the years.

Liquidity Liquidity ratios, such as debt service coverage ratio (DSCR), debt equity ratio, debt to capital turnover, were found to be kept at acceptable levels of 3.35, 1.19, $29.72 \%$, respectively.

These ratios show that the processing plant is able to meet its obligations on long-term liabilities. Further decreasing trend (Table 7) of all these ratios shows that the debt obligations go on decreasing over the years and also along with capacity. 
Table 7 Financial feasibility ratios of small-scale unit of sundried meat production

\begin{tabular}{|c|c|c|c|c|c|c|c|c|c|}
\hline \multirow[t]{2}{*}{ Financial feasibility ratio } & \multicolumn{9}{|l|}{ Year } \\
\hline & 1 & 2 & 3 & 4 & 5 & 6 & 7 & 8 & Average \\
\hline \multicolumn{10}{|l|}{ Profitability ratios } \\
\hline Gross profit margin $(\%)$ & 19.15 & 19.15 & 19.15 & 19.15 & 19.15 & 19.15 & 19.15 & 19.15 & 19.15 \\
\hline Operating profit margin (\%) & 11.92 & 11.92 & 11.92 & 11.92 & 11.92 & 11.92 & 11.92 & 11.92 & 11.92 \\
\hline Profit margin $(\%)$ & 9.09 & 9.09 & 9.09 & 9.09 & 9.09 & 9.09 & 9.09 & 9.09 & 9.09 \\
\hline Net profit margin $(\%)$ & 8.64 & 8.64 & 8.64 & 8.64 & 8.64 & 6.59 & 6.59 & 12.70 & 8.63 \\
\hline \multicolumn{10}{|l|}{ Investment ratios } \\
\hline Return on total investment (\%) & 23.37 & 23.37 & 23.37 & 23.37 & 23.37 & 17.84 & 17.84 & 34.36 & 23.36 \\
\hline Return on equity (\%) & 93.49 & 93.49 & 93.49 & 93.49 & 93.49 & 71.35 & 71.35 & 137.46 & 93.45 \\
\hline Investment turnover ratio & 4.28 & 4.28 & 4.28 & 4.28 & 4.28 & 5.61 & 5.61 & 2.91 & 4.44 \\
\hline \multicolumn{10}{|l|}{ Liquidity ratios } \\
\hline Debt equity ratio & 2.11 & 2.11 & 1.76 & 1.41 & 1.06 & 0.70 & 0.35 & 0.00 & 1.19 \\
\hline Debt to capital turn over & 52.84 & 52.84 & 44.03 & 35.23 & 26.42 & 17.61 & 8.81 & 0.00 & 29.72 \\
\hline Debt service coverage ratio & 7.54 & 2.47 & 2.58 & 2.71 & 2.86 & 2.54 & 2.70 & & 3.35 \\
\hline Operating ratio & 88.08 & 88.08 & 88.08 & 88.08 & 88.08 & 88.08 & 88.08 & 88.08 & 88.08 \\
\hline
\end{tabular}

All the liquidity ratios showed that the debt obligations decrease over time and surpluses generated by plant will go on increasing over time and also along with capacity.

Investment ratios Analysis of investment ratios shows that on an average meat plant is able to generate enough returns of $23.36,93.45 \%$ returns on total investment and equity, respectively. Investment turnover ratio is kept at $4.44 \%$.

To sum up, the financial viability indicators revealed that the processing unit is financially viable. Overall, the processing plant under study showed satisfactory performance on account of liquidity, profitability, and investment.

\section{Economic feasibility}

In the present study, economic feasibility of sun dried processing unit was measured using discounted measures, such as NPV, BCR, IRR, and payback period. The calculated IRR of the project is $41 \%$ and net present value (NPV) at $12 \%$ discount is US\$ 0.09 lakhs, respectively. The positive NPV (Table 8) implied that the discounted worth of benefits was greater than disconnected worth of cost steams. The project's initial investment will be fully recovered in less than 4 years (3.21 years) with average annual net returns of Rs. 3.29 lakhs per annum.

Benefit cost ratio being greater than unity 1.54 reaffirmed that processing plants are viable, and on average, the plants will give a return of 1.54 on every rupee investment on sun dried meat production.

\section{Break even analysis}

Break even analysis indicates that BEP of output is $1941.44 \mathrm{~kg}$ which comes at $56.4 \%$, of utilized capacity and $47.94 \%$ of full capacity of the unit.

Table 9 shows that minimum quantity of $1941.44 \mathrm{~kg}$ per year should be produced in case of small scale dried meat unit, so as to continue production process without sustaining losses. The remaining output $(43.6 \%)$ is considered as margin of safety where profits start generating.

\section{Conclusions}

In this paper, feasibility of a small-scale unit of sun dried meat products was examined using economic measures and project evaluation techniques.

- The results showed that the unit requires initial investment of US\$ 0.17 lakhs.

- The unit incurs annual costs of US\$ 0.43 lakhs at daily costs of US\$ 278.41 with raw material cost accounting for $71.24 \%$ (US\$ 0.3 lakhs).

- Cost of production comes to US\$12.38/kg out of which variable and fixed costs accounts for 86.07 and $12.93 \%$, respectively.

- The unit generates gross and net return of US\$ 0.47 and 0.04 lakhs. in the first year, respectively.

- All the feasibility ratios showed that the dried meat production on small unit is profitable with net profit margin of $8.63 \%$. 
Table 8 Economic feasibility measures for cured meat processing plant

\begin{tabular}{llll}
\hline S. no. & Feasibility measures & Estimate & Required \\
\hline 1 & NPV (discounted) (Rs. lakhs) & 0.09 & Should be positive \\
2 & IRR (\%) & $41 \%$ & $>$ Cost of capital \\
3 & BC & 1.54 & $>1$ \\
4 & Average returns (undiscounted) & 0.05 & - \\
5 & Payback period (years) & 3.21 & Less \\
6 & Average returns (discounted) & 0.01 & - \\
7 & DSCR & 3.34 & $>1.5$ \\
\hline
\end{tabular}

Table 9 Break even analysis for chicken nuggets on different size groups of units

\begin{tabular}{lllllllll}
\hline Particulars & 1 & 2 & 3 & 4 & 5 & 6 & 7 \\
\hline Total output (kg)/year & 3443 & 3443 & 3443 & 3443 & 3443 & 3443 & 3443 & 3443 \\
Break even point (capacity) & 1941.44 & 1941.44 & 1941.44 & 1941.44 & 1941.44 & 1941.44 & 1941.44 & 1941.44 \\
Break even point (as \% of capacity) & 56.40 & 56.40 & 56.40 & 56.40 & 56.40 & 56.40 & 56.40 & 56.40 \\
Break even point (as \% of full capacity) & 47.94 & 47.94 & 47.94 & 47.94 & 47.94 & 47.94 & 47.94 & 47.94 \\
Total revenue (US\$ lakhs) & 0.26 & 0.26 & 0.26 & 0.26 & 0.26 & 0.26 & 0.26 & 0.26 \\
Total variable cost (US\$ lakhs) & 0.21 & 0.21 & 0.21 & 0.21 & 0.21 & 0.21 & 0.21 \\
Total fixed cost (US\$ lakhs) & 0.06 & 0.06 & 0.06 & 0.06 & 0.06 & 0.06 & 0.06 & 0.06 \\
Total cost (US\$ lakhs) & 0.26 & 0.26 & 0.26 & 0.26 & 0.26 & 0.26 & 0.26 & 0.26 \\
Profit & 0 & 0 & 0 & 0 & 0 & 0 & 0 \\
\hline
\end{tabular}

- According to the discounting criteria, the small processing plant of sun dried meat products under study turned out to be economically viable with NPV of US\$ 0.09 lakhs and IRR of $41 \%, \mathrm{BC}$ ratio of 1.54 , and payback period of 3.21 years. The plant generates average returns of US $\$ 0.05$ lakhs per year.

- Economic analysis showed that the business of smallscale production of dried meat on the family farm is profitable

- Considering the importance of poultry meat in Indian diet, it is important to explore the possibilities of availability throughout year. Processing of meat into durable products during surplus production go a long way in reducing the post harvest losses.

- India being agricultural dependent country faces offseason unemployment in rural areas. Providing employment to rural people in off-season is a major challenge for the govt. In this situation, self-employment opportunities have to be provided.

- Solar drying is one such technology which empowers rural people through off-season employment. Being situated in tropics, India is endowed with natural and conventional, renewable solar energy for almost 6 months which provides opportunities for dried products. Integrating livestock with the conventional energy can become an alternative employment and revenue generating source in the off-season in the rural areas.
- The construction of small plants for drying meat can be a good way for increasing income of family farms, reduction of unemployment and overall development and economic empowerment of the rural India. Serious subsidy programs for building mini dryer as well as support for export products in the initial stages as the use of dried meat is not explored in India would significantly contribute to the development of this business.

- Hence, government has to take necessary measures to take this technology to rural areas and also should give support in terms of skill development for the use this technology for production of safe and healthy foods and make its adoption a success. This helps in ensuring dual purpose of rural development through employment generation in rural areas and availability of foods throughout the year for consumption. Thus, the twin objectives of rural and national development and environment management can be achieved with conventional energy like solar energy.

Open Access This article is distributed under the terms of the Creative Commons Attribution 4.0 International License (http://crea tivecommons.org/licenses/by/4.0/), which permits unrestricted use, distribution, and reproduction in any medium, provided you give appropriate credit to the original author(s) and the source, provide a link to the Creative Commons license, and indicate if changes were made. 


\section{References}

1. http://nsdl.niscair.res.in/jspui/bitstream/123456789/554/1/Con cepts $\% 20$ of\%20rainfed\%20agriculture\%20-\%20Formatted.pdf. Accessed 10 Nov 2015

2. http://www.icar.org.in/files/forage-and-grasses.pdf. Accessed 10 Nov 2015

3. http://www.nrega.nic.in/netnrega/home.aspx. Accessed 10 Nov 2015

4. Ladipo, J.K., Ossai, G.E.A., Olunloyo, O.A.: Food science and technology in national development: entrepreneurship in the food industry. Niger. Food J. 4, 3-11 (1986)

5. http://dahd.nic.in/dahd/WriteReadData/FINAL\%20ANIMAL\% 20AR\%202013-14\%20FOR\%20WEB.pdf. Accessed 6 Oct 2015

6. APEDA: Export of agro and processed food products including meat and meat products. Agricultural and Processed Food Products Export Development Authority. Ministry of Commerce, Government of India (2008)

7. FAO. Development and promotion of value added products. Project Document, FAO, Rome. (1995)

8. https://books.google.co.in/books?isbn=1439836833. Accessed 10 Nov 2015
9. Mujumdar, A.S., Devahastin, S.: Fundamental principles of drying. In: Mujumdar, A.S. (ed.) Guide to Industrial Drying-Principles, Equipments and New Developments. Three S Colors Publications, Mumbai (2008)

10. Chen, X.D., Mujumdar, A.S.: Drying Technologies in Food Processing. Wiley-Blackwell, West Sussex (2008)

11. Jangam, S.V., Law, C.L. and Mujumdar, A.S. Drying of Foods, Vegetables and Fruits, vol 1. ISBN 978-981-08-6759-1. Published in Singapore (2010). http://serve.me.nus.edu.sg/arun/file/ Publications/books/Drying\%20of\%20Foods\%20Vegetables\% 20and\%20Fruits\%20Volume\%201.pdf. Accessed 12 Nov 2015

12. http://archive.unu.edu/unupress/unupbooks/80478e/80478E0g. htm. Accessed 12 Nov 2015

13. http://www.conserve-energy-future.com/various-solar-energyfacts.php. Accessed 12 Nov 2015

14. http://www.fao.org/docrep/010/ai407e/ai407e18.htm. Accessed 12 Nov 2015

15. Vukoje, V., Pavkov, I.: Analysis of economic justification of drying of apricots by combined tehnology. PTEP 14(1), 36-39 (2010)

16. http://as.ori.nic.in/diorissa/guidelines_28.08.12.pdf. Accessed 6 Oct 2015 